\title{
Entre silêncios e ruídos: a anistia na Assembleia Constituinte de 1987/88
}

Mayara Paiva Souza* Noé Freire Sandes*

Resumo: Este texto tem por objetivo analisar os debates acerca da anistia e os usos do passado na Assembleia Constituinte de 1987/88. A partir de tais debates podemos perceber como o passado foi posto em negociação, reinterpretado e difundido em meio a um processo de transição política que visava à passagem de um regime discricionário para a consolidação de um regime democrático. Por meio das negociações em torno da anistia o jogo entre a lembrança e o esquecimento aparece como estratégia política para aqueles homens envolvidos na construção de um novo regime político no país. Dessa forma o passado ditatorial foi negociado a partir dos embates políticos e embates de memória que foram travados no contexto da transição e culminaram no plenário da Constituinte. Dentro desse quadro, a partir dos diários e anais das Assembleia Constituinte, bem como de periódicos e obras memorialísticas, pretende-se avaliar, por intermédio dos debates acerca da anistia, as estratégias e negociações em torno do passado, e de sua interpretação, no período. Assim, analisamos os usos do passado: os embates políticos, os silêncios e ruídos que deixaram marcas, cicatrizes e questões que ainda hoje aguardam respostas. Interlocução complexa que se situa entre o terreno da memória e da história.

Palavras-chave: Anistia. Memória. Assembleia Nacional Constituinte (1987/88).

"Doutora em História pela Universidade Federal de Goiás - UFG. Professora da Secretaria de Educação de Goiás e da Prefeitura Municipal de Goiânia. E-mail: mayaratapajos@hotmail.com

Doutor em História pela Universidade de São Paulo - USP. Professor titular de História do Brasil na Universidade Federal de Goiás - UFG. E-mail: freiresandes@gmail.com 


\section{Introdução}

De nossa primeira leitura do clássico A memória coletiva, de Maurice Halbwachs (1990), no início da graduação em História, ficou-nos registrada - de certa forma - a fatídica impressão: ninguém acredita naquilo de que apenas eu me lembro. Mesmo que o sujeito se lembre, ele carece de escuta, de partilha, carece do próximo. Dessa forma, acreditamos que a constante busca da memória e da História está justamente no reconhecimento, na audição e na identificação. Afinal, narramos para sermos ouvidos.

Segundo Paul Ricoeur (2007), a memória almeja reencontrar a imagem do passado e reconhecê-la; a História, por meio dos vestígios deixados pela memória, também almeja o reconhecimento. Assim, nós, historiadores, esperamos dos pares e dos leitores o reconhecimento da autenticidade do que narramos. Assim como Ulisses foi reconhecido por sua cicatriz e, dessa forma, retomou o seu lugar no trono de Ítaca ${ }^{1}$, a História e a memória, apesar de todos os percalços da "viagem", buscam as marcas que permitam que o passado seja reconhecido e "autenticado".

Nesta perspectiva, as questões que abordamos neste texto advêm de inquietações cultivadas há longo prazo, isto é, a relação entre a anistia e a narrativa histórica. Durante nossas leituras sobre os processos de anistia no Brasil, algumas questões voltadas para o ofício do historiador se tornaram pujantes: até que ponto a anistia, este "esquecimento comandado", pode afetar a escrita da História? A anistia pode comprometer a busca pelo reconhecimento do passado empreendida pela memória e pela História? Ou mesmo, até que ponto a anistia corresponde ao esquecimento?

Em sentido político, a anistia - termo que carrega consigo a relação entre passado, presente e futuro ${ }^{2}$ - é o caminho a ser percorrido para a "pacificação dos espíritos" após um período de turbulência política. A origem do termo remete-nos aos gregos. Desde a Grécia Antiga, a amnêstia - olvido e redenção - tem sido usada para a conciliação e a pacificação política (MARTINS, 1978).

Rui Barbosa, em seu famoso texto Anistia inversa (1896), afirmou que a medida passa uma esponja sobre os atos do passado que o governo tem dificuldades de punir. Dessa forma, os delitos 
desaparecem juridicamente e são cobertos pelo "véu do eterno esquecimento"; em contrapartida, "cabe à história recolhê-los". Para Rui Barbosa, a anistia é um ato que cicatriza as feridas e repõe as coisas no lugar, portanto, um esquecimento positivo que possibilita a conciliação política da nação. Para que o passado se cicatrize totalmente, cabe à História narrar os fatos.

Em contraposição ao pensamento de Rui Barbosa, apresentado no final do século XIX, o filósofo francês, Paul Ricoeur, que escreveu na segunda metade do século XX, apontou a anistia como um "esquecimento" negativo ao trabalho crítico da memória. Apesar de concordar que o expediente visa à conciliação dos interesses políticos em conflito, a fim de manter a unidade da comunidade, Paul Ricoeur vê na anistia um aspecto nocivo à memória (RICOEUR, 2007). O expediente bane o passado conflituoso como se nada tivesse acontecido, tornando-se uma "amnésia comandada". Nesse sentido, a anistia suspende os processos judiciais apagando os crimes por ela contemplados. Todavia, tal medida priva a opinião pública do benefício do dissenso, do "trabalho de luto" que acomoda o passado em uma narrativa que faça sentido para o presente e, desta forma, permita que o homem siga em frente.

Para o filósofo francês, a anistia é um abuso do esquecimento, pois tenta criar um fosso entre passado e presente. Cria páginas em branco, sobre as quais é impossível escrever outra História, visto as rugosidades deixadas pelo processo de apagamento. Contudo, há a memória prenhe de conflitos de quem viveu a experiência anistiada e, mesmo que se tente eliminar o passado por um meio jurídico, é impossível eliminar a memória sem que quem tenha vivido o período busque, de fato, esquecer. De acordo com Ricoeur (2007), se há uma forma de esquecimento legítimo, esta não está em calar o mal, mas em dizê-lo de modo apaziguado, sem cólera. Entretanto, o esquecimento não partirá de um mandamento, de uma ordem, mas do desejo de esquecer.

Guiados por tais questões, optamos por analisar os debates sobre a anistia na Assembleia Nacional Constituinte de 1987/88, período de transição de uma longa experiência política ditatorial para a tão esperada democracia. Dessa forma, tais debates, publicados pelos diários e anais da Assembleia Nacional Constituinte, 
disponíveis na página virtual da Câmara dos Deputados, foram tomados como principais fontes para a realização desta pesquisa.

Selecionamos o tema da anistia no contexto da Assembleia Constituinte por pressupormos que, ao trazer consigo as negociações em torno do passado e futuro, tal tema pode nos dar pistas acerca das negociações voltadas para o processo de gestão da memória da Ditadura. Desse modo, partimos da perspectiva de que a Assembleia Nacional Constituinte de 1987/88 representou ambiente propício, não apenas para os debates político-partidários, mas também para os embates entre memória e História.

Em 1a de fevereiro de 1987, durante o governo de José Sarney - primeiro presidente civil após 21 anos de governo militar - Deputados e Senadores reuniram-se em Assembleia Nacional Constituinte para elaborarem a nova Constituição Brasileira. A Assembleia, composta por 559 parlamentares - dos quais 306 faziam parte do PMDB - distribuídos entre 13 partidos $^{3}$ e presidida por Ulysses Guimarães, tinha a difícil missão de consolidar a transição política democrática e sepultar os longos anos de ditadura.

Vista como momento de transição, a Assembleia tinha a difícil tarefa de levar o futuro a superar o passado. Entretanto, tal tarefa apontava para um campo de negociações bastante delicado: à sombra dos parlamentares, que traziam consigo as experiências vividas ao longo da ditadura, estava um governo ainda marcado por fortes resquícios do passado ditatorial. Foi nesse ambiente de expectativas, mas também de receios acerca de um possível retorno de um passado que ainda estava à espreita, que a anistia foi debatida e, desse modo, tornou-se um dos temas mais polêmicos e delicados na Assembleia Constituinte.

Apesar de a anistia ter sido aprovada em agosto de 1979, durante o governo do General João Batista Figueiredo, o tema chegou à Assembleia Constituinte de 1987/88 envolto em um intenso debate que abrangia a luta das vítimas da ditadura contra a impunidade dos agentes do Estado e, também, a busca de tais vítimas por reparação. ${ }^{4}$

Coroação do processo de transição democrática, a Assembleia Constituinte era alvo de interesses de diversos grupos, sejam ligados à expectativa de consolidar o passado, ou de sepultá-lo em prol do futuro. Dividida em Comissões e Subcomissões ${ }^{5}$, a Assembleia 
reunia parlamentares que traziam consigo experiências de um longo regime autoritário. Para muitos parlamentares a nova Constituição representava a oportunidade de sepultar, de vez, a ditadura. Para outros, mesmo que de forma velada, a nova Constituição poderia ser o meio de consolidar políticas herdadas do passado ditatorial. ${ }^{6}$ Para ambas correntes, a Assembleia Nacional Constituinte era o ponto focal, a encruzilhada entre o passado e o futuro. Desse modo, ao estabelecermos como objeto de pesquisa o debate sobre a anistia, pretendemos analisar qual caminho foi traçado pelos parlamentares nesse espaço de negociações entre a experiência e a expectativa; entre a memória, o esquecimento e o silêncio.

Segundo Elizabeth Jelin (2001), as aberturas políticas após períodos autoritários habilitam a esfera pública a incorporar narrativas e relatos até então desconhecidos ou censurados. Além disso, tais transições democráticas abrem espaço para novos relatos, para o que, até estão, estava silenciado. Essa abertura implica um cenário de luta pelo sentido do passado, envolvendo uma pluralidade de atores e agente com múltiplas demandas e reivindicações. Nessa perspectiva, parte-se do pressuposto que a Assembleia Nacional Constituinte de 1987/88 representava esse espaço de abertura e audição para múltiplas vozes, entretanto ao organizarem sua interpretação sobre o passado recente, as experiências dos constituintes se chocavam devido às distintas representações da lembrança e as diferentes formas de buscarem a conciliação da nação. Enquanto grande parte da Assembleia via no silêncio o principal caminho para o apaziguamento dos conflitos do passado, ao longo dos debates sobre a anistia podemos perceber "ruídos" que viam no "luto" sobre o vivido e na necessidade de evidenciar o passado como a única forma de reparar as injustiças ocorridas ao longo da ditadura. Desse modo, os debates sobre a anistia revelam esse embate entre a exumação ou o soterramento do passado. Resta saber qual via se sobressairia ao longo dos trabalhos daquela Assembleia.

Travava-se uma batalha de memórias voltada para a construção do futuro. $\mathrm{O}$ passado era negociado e, por vezes, chamado a testemunhar, visto que aqueles parlamentares ainda estavam cativos da experiência ditatorial. Tanto para os aliados do regime anterior quanto para os opositores, para garantir a experiência do 
presente e consolidar o futuro almejado, era necessário conciliar o passado. Todavia, qual seria o melhor caminho para a pacificação da experiência ditatorial, o julgamento do passado ou o silêncio como meio de construção do devir?

A negociação em torno da gestão da memória, o jogo entre o lembrar e o esquecer, é um processo dinâmico que flui de acordo com as modificações sociais e temporais, processo influenciado por transformações políticas e também pelo surgimento de novos atores sociais que podem modificar os mirantes pelos quais vemos o passado (JELIN, 2002). Todavia, assim como a lembrança, o silêncio também pode ser utilizado, consciente ou inconscientemente, para determinados fins. Pode, de acordo com o cenário político e social - individual ou coletivo - ser conveniente para a manutenção dos interesses do presente. E dessas conveniências, podemos pressupor que o outrora silenciado - memória subterrânea - (POLLAK, 1979) também pode emergir em determinadas conjunturas e se tornar, finalmente, memória.

Para os constituintes de 1987/88, o passado não era terra estrangeira (LOWENTHAL, 1998), suas lembranças ainda influenciavam o sentido que atribuíam ao regime ditatorial. Além disso, muitos parlamentares ainda carregavam a bagagem do passado. Interessanos saber se naquele espaço de negociação política decidiriam levar consigo a experiência, ou soterrá-la pelo caminho.

\section{Os debates sobre a anistia}

\section{Ruídos: os primeiros debates sobre a anistia na Assembleia Nacional Constituinte}

Em 1985, em plena transição política no Brasil, o escritor Luiz Fernando Veríssimo publicou o seguinte texto:

Não é fácil eliminar um corpo. Uma vida é fácil. Uma vida é cada vez mais fácil. [...] Os desaparecidos não desaparecem. Sempre há alguém sobrando, sempre há alguém cobrando. As valas comuns não são de confiança. A terra não aceita 
cadáver sem documentos. Os corpos são devolvidos, mais cedo ou mais tarde. A terra é protocolar, não quer ninguém antes do tempo. A terra não quer ser cúmplice. Tapar os corpos com escombros não adianta. Sempre sobra um pé, ou uma mãe. Sempre há um bisbilhoteiro, sempre há um inconformado. Sempre há um vivo. [...] Sempre sobra um dedo acusando. O corpo é como o nosso passado, não existe mais e não vai embora. Tentaram largar o corpo no meio do mar e não deu certo. O corpo boia. O corpo volta. Tentaram forjar o protocolo - foi suicídio, estava fugindo - e o corpo desmentia tudo. $\mathrm{O}$ corpo incomoda. O corpo faz muito silêncio. Consciência não é biodegradável. Memórias não apodrecem. Ficam os dentes. (VERÍSSIMO, 1985).

Veríssimo publicou o texto no ano em que chegava ao fim a ditadura militar no país com a eleição de um presidente civil. $\mathrm{O}$ governo militar deixava atrás de si um rastro de vinte e um anos de violência e repressão política. Diante da eminente abertura política e da volta ao regime democrático, restava ao governo à seguinte questão: o que fazer com o passado de repressão? Como destacado por Veríssimo, o passado não é facilmente eliminado, sempre haverá um vivo cobrando explicações sobre os acontecimentos pretéritos, isso não fora diferente na Assembleia Constituinte, espaço que contou com intensa pressão das vítimas da ditadura que continuavam na busca por reparação. Q Quase uma década após a anistia, diante do empenho do governo em silenciar o passado, as vítimas continuavam empenhadas em evidenciar as diversas camadas de recordação encapsuladas pelo cerco do silêncio. Foi nesse embate entre soterrar e escavar que o tema da anistia chegou à Assembleia Nacional Constituinte de 1987/88, como afirmara Veríssimo (1985), o passado, apesar de não mais existir, não iria embora sem que recebesse a devida sepultura.

Os debates sobre a anistia no contexto de funcionamento da Assembleia Nacional Constituinte de 1987/88 evidenciam que naquele período de transição democrática, apesar da anistia de 1979, ainda havia demandas que impediam que o passado fosse, por fim, sepultado. Dentre as pendências deixadas pela lei de anistia, saltam 
à vista duas questões centrais, quais sejam: a impunidade em relação aos crimes cometidos por agentes do Estado e a exclusão da anistia aos ex-militares cassados ao longo da ditadura.

É notório que o Estado brasileiro tentou silenciar a repressão que promovera ao longo da ditadura militar. Esse processo de silenciamento advinha de longa data, com as práticas de desaparecimento de corpos, destruição de arquivos, desqualificação moral da oposição e negação da tortura (FERRAZ, 2007). A última "pá de cal” foi lançada pela lei de anistia de 1979 a fim de soterrar de vez a opressão cometida ao longo do regime militar. Todavia, sabemos também que o que é soterrado, pode, por vezes, retornar e assombrar o presente.

Privado de um trabalho de luto, o passado confiscado tornou-se ferida aberta e de difícil cicatrização. Dentro desse quadro, parte-se, aqui, do pressuposto - ao seguir as reflexões de Paul Ricoeur (2007) - que a fenda aberta pela anistia dificulta esse processo de cicatrização, primeiro porque tenta construir um cerco de esquecimento em torno do passado, segundo porque garante a impunidade aos beneficiados pela medida. Dessa forma, resta às vítimas agarraremse as lembranças para que tal passado não se perca e para que haja o reconhecimento da experiência.

Em 1987 eram imensas as expectativas para que, por fim, a Assembleia Constituinte conseguisse resolver os imbróglios do passado ditatorial. Os militares cassados pelo regime ditatorial buscavam a reparação por meio da reversão aos seus antigos cargos e pelo reconhecimento do passado, e enviaram à Assembleia um lobby que se empenhou em pressionar os parlamentares para que a anistia fosse ampliada e os cassados reparados. ${ }^{8}$ Da mesma forma, os familiares de mortos e desaparecidos buscavam reparação, entretanto almejavam que a reparação fosse feita pela via da responsabilização dos agentes da repressão. Além disso, os familiares, representados na Constituinte pelo grupo Tortura Nunca Mais, almejavam a reparação histórica, isto é, era preciso que a História do período fosse contada e o paradeiro das vítimas revelado para que tais atrocidades nunca mais se repetissem. Nesse sentido, as vítimas esperavam que a Constituinte desatasse, definitivamente, o nó do passado, seja por meio do apagamento das punições, seja por meio da punição aos envolvidos com os atos arbitrários da ditadura. 
Entretanto, a pressão sobre a Assembleia não vinha apenas de quem buscava reparar o passado, mas também do olhar atento dos militares. Personagens centrais nos embates de memórias travados na Assembleia Constituinte, os militares, que compunham a linha de frente do governo de José Sarney, ficariam atentos a cada debate travado na Assembleia. ${ }^{9}$ Como destacou Eliézer Rizzo de Oliveira (1994), os militares prepararam-se com antecedência para acompanharem os trabalhos da Constituinte. Apoiados em assessorias atuantes no Congresso, mobilizaram apoios, identificaram os aliados e combateram ideias distintas de suas propostas. Além de um atuante $l o b b y^{10}$ na Constituinte, havia, ainda, a pressão dos ministros militares na imprensa, principalmente do Ministro do Exército, General Leônidas Pires Gonçalves, que se valeu da influência que exercia sobre o Presidente Sarney para pressionar a Assembleia (SARNEY..., 1988). Ao longo do trabalho da Constituinte, por meio de entrevistas aos principais jornais do país ou por notas oficiais, os ministros militares deixavam claro o seu posicionamento sobre o trabalho dos parlamentares e mandavam seu recado sobre o que admitiriam, ou não, na nova Carta Magna.

Diante da pressão que vinha tanto da experiência quanto da expectativa, o deputado César Maia (PDT/RJ) destacou sua preocupação com o peso do passado na Constituinte:

Nós vamos ter que colocar na nossa Constituição a nossa História. Mas me preocupa que nós coloquemos na nossa constituição os nossos traumas. Eu sou ex-preso político, fiquei exilado muitos anos, recebi maus tratos naquela época, mas não posso colocar esses problemas numa Carta que tem que ser permanente. (BRASIL, 1987, p. 59).

Para o deputado, ex-integrante do Partido Comunista Brasileiro, o passado não deveria contaminar o futuro. Apesar de consciente da dificuldade de abrir mão da experiência, o parlamentar advertia para o perigo de se colocar em primeiro plano as experiências pessoais. César Maia preocupava-se com a possibilidade de que os ressentimentos e traumas de cada parlamentar, que sofrera as agruras da ditadura, influenciassem a elaboração da nova Constituição 
brasileira, uma vez que os Constituintes ainda se encontravam aprisionados na experiência ditatorial. O parlamentar, vítima do regime, apontava para a necessidade de conciliação, visto que os traumas do passado não poderiam determinar o futuro a ser elaborado naquela Constituinte.

Dentro desse quadro de tensão, de ressentimentos e ruídos do passado, os debates sobre a anistia na Assembleia Constituinte de 1987/88 seguiram um percurso bastante polêmico e marcado por diversas vicissitudes. Tratado primeiramente nas Subcomissões e Comissões, o tema envolveu grandes expectativas de rompimento com o entulho do passado autoritário.

O debate sobre a anistia apareceu primeiramente na Subcomissão dos Direitos Políticos, Coletivos e Garantias. O relator da Subcomissão, deputado Lysâneas Maciel (PDT-RJ) - antigo autêntico do MDB, parlamentar cassado durante a ditadura militar, exilado e anistiado - propôs uma anistia ampla e que reparasse, definitivamente, as injustiças cometidas contra civis e militares ao longo do regime ditatorial. Em 14 de maio de 1987, o relator apresentou à Subcomissão um projeto que ampliava o período de abrangência da anistia aos atingidos pelo arbítrio da ditadura, e incluía, também, os que foram punidos por sanções disciplinares baseadas em atos administrativos, medida que beneficiaria os militares punidos após o golpe de 1964. Além disso, sua proposta de anistia previa reparação econômica e promoção, como se os servidores tivessem permanecido em atividade durante a ditadura militar (BRASIL, 1987a).

A proposta de apagamento das arbitrariedades do passado funcionaria até certo ponto, uma vez que beneficiaria os servidores cassados e punidos que foram afastados de suas funções. Ao retornarem a seus cargos e receberem indenizações, os servidores teriam as injustiças reparadas e poderiam seguir adiante sem ressentimentos. Todavia, no que se refere aos mortos e desaparecidos, apesar de o projeto de Lysâneas Maciel prever indenizações para os familiares, a impunidade e a falta de história, a ausência de justificativas e de pistas sobre o paradeiro das vítimas, a falta de um corpo e de um ponto final impossibilitavam que tal passado passasse. Nesse sentido, os familiares não viam no silêncio um caminho para a conciliação, pleiteavam, muito mais do que indenizações, o julgamento e 
a punição dos envolvidos. Mas nem mesmo Lysâneas Maciel, um dos parlamentares que mais lutou contra a ditadura, estava disposto a revirar os entulhos do passado.

Sob o olhar atento dos militares - que afirmavam que a anistia proposta pela Assembleia era inviável, visto que a reversão dos punidos aos seus antigos cargos seria uma dissolução dos principais feitos do regime instaurado em 1964 (A ANISTIA..., 1987) - Lysâneas Maciel encaminhou o anteprojeto para a Comissão de Soberania e dos Direitos e Garantias do Homem e da Mulher, mantendo uma proposta de anistia reparadora. $\mathrm{O}$ anteprojeto visava à justiça aos que foram punidos durante o regime ditatorial; em contrapartida, a justiça aparecia no projeto do deputado não por meio do julgamento dos envolvidos na repressão, mas por meio da reparação financeira e do retorno aos antigos cargos. A anistia como reparação surgia como uma possibilidade de unir as pontas do passado com o futuro; como uma dissolução da experiência vivida ao longo do regime ditatorial.

$\mathrm{Na}$ Comissão de Soberania e dos direitos e garantias do homem e da mulher, o projeto ficou sob a responsabilidade do senador José Paulo Bisol (PMDB-RS) - juiz cassado após o golpe de 1964 escolhido como relator daquela Comissão. A polêmica continuou em torno da anistia aos militares cassados. Muitos parlamentares argumentavam que a anistia aos militares atingidos por atos administrativos e disciplinares após o golpe de 1964, prejudicaria os princípios básicos das Forças Armadas, isto é, a disciplina e a hierarquia. A reversão dos "subversivos" à ativa era vista como uma forma de corromper e "contaminar" novamente as Forças Armadas com o "vírus" que marcara as gerações anteriores, isto é, o "vírus comunista" (MINISTROS..., 1987).

Apesar da polêmica, o senador Bisol manteve os benefícios aos militares punidos e, indo mais além, ampliou a reparação aos que foram exilados e aos parlamentares cassados durante a ditadura. Ao contrário do que pretendiam os militares e constituintes conservadores, na Comissão temática o projeto de Lysâneas Maciel não foi "enxugado" e sim ampliado por Bisol que, àquela altura, era acusado de elaborar um projeto socialista (CONSERVADORES..., 1987). 
A anistia também figurou entre os temas debatidos na Comissão de Ordem Social que recebera o anteprojeto da Subcomissão dos Direitos dos Trabalhadores e Servidores Públicos. Em seu projeto, o relator Almir Gabriel (PMDB-PA) também manteve o alcance da anistia para os ex-militares cassados após o golpe de 1964, bem como para os punidos pelo levante de 1935 e pela campanha "o Petróleo é Nosso"."

Dessa forma, apesar da pressão dos militares, o projeto de anistia fora aprovado nas duas Comissões temáticas onde fora debatido na Assembleia Constituinte. Entretanto, no momento em que a ampliação da anistia parecia garantida, os ministros militares não relutaram em afirmar que não cumpririam as decisões da Constituinte no que se refere à anistia. Os ministros se pronunciaram na imprensa afirmando que não aceitariam devolver fardas aos punidos pela "Revolução" (MINISTROS..., 1987).

Sobre o cerco dos militares à Constituinte, o assessor parlamentar, Alaor Barbosa, escreveu em seu diário:

o Ministro do Exército, General Leônidas Pires Gonçalves, declarou que não pagará aos militares que vierem a se reintegrar no Exército por força da anistia. A reação dos constituintes [...] foi tímida; eles preferiram ignorar, ou fingir que não tinham importância as palavras do general ministro. Hoje - disse a televisão, num noticiário a que assisti há duas horas e pouco - o General Leônidas voltou a afirmar, no Palácio do Planalto, que é contrário à anistia projetada na Assembléia Nacional Constituinte, e que esta se acha dominada por radicais. (BARBOSA, 1990, p. 162-163).

Dentro desse quadro de polêmicas envolvendo as Forças Armadas e a Constituinte, o jornal O Estado de São Paulo ressaltou que os ministros não tinham a menor simpatia pelo projeto de anistia da Assembleia Constituinte; dessa forma, adotariam outra tática no que se relaciona à anistia, levariam o assunto diretamente ao Presidente da República. Segundo o periódico, os militares não mais pretendiam discutir a questão da anistia da forma como estava redigida na Assembleia Constituinte, uma vez que o texto, segundo eles, 
eliminava todas as possibilidades de entendimento. Nesse sentido, os ministros militares destacavam que a partir daquele momento o assunto só poderia ser resolvido entre o presidente da República e as Forças Armadas (OUTRA..., 1987). Diante desse conflito instaurado pela anistia aos ex-militares cassados, a soberania da Assembleia era desafiada pelas Forças Armadas. Passado e futuro entravam novamente em confronto.

Apesar da polêmica travada em torno da possibilidade de retorno dos militares cassados à ativa, isto é, da dissolução do passado, os crimes cometidos pelos agentes da ditadura continuavam cercados pelo silêncio. Conscientes da existência de tal passado, os constituintes seguiam ignorando-o e tentando mantê-lo à devida distância do presente. Em meio às propostas que visavam a conciliação, uma questão se tornava latente na Constituinte: quem pagaria pelas cassações, prisões, exílios e torturas? Os parlamentares não pareciam dispostos a buscarem culpados pela repressão, mas apenas reparar erros e injustiças cometidas pelo regime militar e, dessa forma, apagar um passado que deixara marcas profundas na sociedade brasileira. Nesse sentido, a anistia era tratada literalmente como esquecimento e dissolução do vivido.

De acordo com Renan Quinalha (2013), em períodos de transições políticas, apesar dos esforços, é impossível ignorar o passado. Desse modo, não se pode recomeçar de onde se tinha parado, como se nada tivesse acontecido. A experiência ditatorial deixa marcas profundas tanto nas experiências individuais como coletivas, nesse sentido, é impossível seguir adiante e ignorá-las. Em outras palavras, o desafio da transição não se resume à mera restauração da democracia, como se sua finalidade fosse apenas recolocar os trilhos no lugar, mas dentre os principais desafios de períodos de transição democrática está a promoção da justiça.

Um dos primeiros passos para que se promova justiça está, justamente, na anistia, daí a polêmica em torno do tema na Assembleia Constituinte. Oscilando entre o lembrar e esquecer, a anistia representava uma verdadeira espada de Dâmocles sobre a Assembleia; desta forma, apesar das benesses, a ameaça militar poderia paralisar os parlamentares. 


\section{Silêncios: o debate final}

Após os debates nas Subcomissões e Comissões Temáticas, os parlamentares encaminharam uma proposta de anistia ampla, geral e irrestrita aos punidos e cassados ao longo da ditadura. Entretanto, mantinham os agentes da repressão sob o manto da impunidade. Diante do "frágil presente", os parlamentares se silenciavam acerca dos crimes da ditadura e legavam ao futuro a tarefa de julgar o passado, se preocupando, por ora, apenas com a dissolução do vivido.

Ponto de convergência entre experiência e expectativa, após meses de debates em Subcomissões e Comissões, a Assembleia chegou à fase decisiva de seus trabalhos: a Comissão de Sistematização. ${ }^{12}$ Com propostas consideradas extremamente progressistas e diante da pressão das Forças Armadas, a Assembleia tinha a difícil tarefa de conciliar a pressão que vinha do passado com as expectativas que clamavam pelo futuro.

Ciente de que todo o trabalho realizado nas Comissões Temáticas poderia ser desfeito pela "poderosa" Comissão de Sistematização, o parlamentar Lysâneas Maciel, antigo "autêntico do MDB”, entrincheirou-se contra a ingerência dos militares na Constituinte e passou a cobrar um posicionamento firme dos parlamentares. Segundo o deputado, ou os parlamentares encaravam o passado com destemor, ou o futuro e a História seriam implacáveis (BRASIL, 1987b, p. 20). Desse modo, Lysâneas destacou o ambiente de temor entre os parlamentares em relação à fragilidade do período:

Nunca tivemos coragem de criticar os militares, não porque eles fossem mais honestos ou mais capazes do que os civis. Não os criticávamos por medo, e hoje temos receio de desestabilizar o processo de transição. [...] Ou temos a coragem de enfrentar isto ou não haverá transição democrática. (BRASIL, 1987b, p. 19).

Para Lysâneas o governo de Sarney representava um "militarismo requentado" e apenas a anistia e a dissolução dos feitos da ditadura poderiam abrir o caminho para a consolidação da democracia. 
A leitura dos projetos, debates e emendas apresentadas na Comissão de Sistematização ${ }^{13}$ revelam que a maioria dos parlamentares, além da disposição de esquecer o passado, ainda temia a permanência deste. O projeto elaborado pelo deputado Bernardo Cabral (PMDB-AM), relator da Comissão de Sistematização, demonstra que a pressão das Forças Armadas sobre a Assembleia não fora em vão, suas principais exigências foram atendidas pela Constituinte. Dentre tais exigências figurou a anistia restrita.

$\mathrm{Na}$ Comissão de Sistematização, o projeto de anistia aprovado anteriormente em duas Comissões Temáticas perdera força. Acusado de desconsiderar os trabalhos realizados nas Comissões Temáticas, e esquecer-se que também fora vítima da ditadura ${ }^{14}$, o relator do projeto, deputado Bernardo Cabral (PMDB-AM), acabou contemplando as reivindicações castrenses. Cabral apresentou um projeto que concedia anistia exclusivamente política, isto é, excluía do benefício todos os punidos por atos administrativos. Em outras palavras, os militares que reivindicavam voltar às fileiras das Forças Armadas continuariam sem a anistia.

A proposta de exclusão da anistia aos militares cassados gerou intenso debate na Comissão de Sistematização, uma vez que o fato era visto pelos parlamentares que defendiam a anistia ampla - como Lysâneas Maciel e José Paulo Bisol - como uma forma de a Constituinte render-se ao Executivo e às Forças Armadas abdicando de sua soberania. A Assembleia curvava-se diante do passado e, de certa forma, abria mão de prerrogativas essenciais para o advento do futuro.

Preocupado com um futuro que poderia trazer em seu bojo ruídos de um passado insepulto, o deputado Paulo Ramos (PMDB-RJ), major da Polícia Militar, foi uma das principais vozes em defesa da anistia na Comissão de Sistematização. Ao abordar o tema o deputado ressaltou:

Se pretendermos que a Assembléia Nacional Constituinte seja a ponte entre o regime autoritário e a democracia, precisamos da pacificação nacional. Não teremos sossego, paz e tranqüilidade se a anistia não for concedida àqueles que hoje sequer se beneficiaram de um mínimo de anistia. (BRASIL, 1987c, p. 697). 
Enquanto houvesse vítimas, haveria réus e, portanto, seria impossível a conciliação nacional. Nesse sentido, Paulo Ramos apontava para a necessidade de "curar" o passado para que a nação pudesse seguir adiante livre de conflitos, ódios e ressentimentos. Entretanto, tal "cura" viria por meio da dissolução das arbitrariedades do regime militar, não da punição.

Foi nessa tentativa de "cura" do passado por meio de sua dissolução que os parlamentares Vilson de Souza (PMDB-SC), Jamil Haddad (PSB-RJ) e Brandão Monteiro (PDT-MA) apresentaram, na sessão de dezesseis de novembro de 1987, emendas que visavam ampliar a anistia proposta pelo projeto de Bernardo Cabral. ${ }^{15}$

O deputado Vilson de Souza - advogado, expressivo parlamentar de Santa Catarina - ao defender a emenda, que propunha anistia aos afastados de seus cargos por atos administrativos, cobrou de seu partido, o PMDB, coerência com o passado, uma vez que a anistia era um compromisso partidário firmado na convenção do PMDB. Assim, na Assembleia Constituinte, sem demonstrar grande preocupação com a ampliação da anistia e com a punição dos agentes da repressão, o Partido parecia dar as costas a uma de suas principais bandeiras. Em uma crítica ferrenha ao "esquecimento" dos parlamentares, Vilson de Souza cobrou de seu partido que honrasse os compromissos históricos que firmara e que não abrisse mão de sua trajetória:

E consta do programa do PMDB, consta do seu caminhar histórico o compromisso de conceder a anistia ampla e geral a todos os brasileiros. Neste sentido, lembro aos membros do PMDB que a última convenção extraordinária do Partido, realizada em julho deste ano, aprovou moção que propõe a aprovação, de forma incondicional, da anistia ampla, geral e irrestrita. (BRASIL, 1987b, p. 421).

Para o parlamentar, o projeto de Bernardo Cabral não tinha coerência com a trajetória de seu partido. Além de apontar os compromissos assumidos na convenção do PMDB em 1987, Vilson de Souza cobrou de Ulysses Guimarães que cumprisse as promessas feitas em declarações à imprensa em 1985, isto é, na ocasião o 
presidente do partido declarara que uma das principais bandeiras do PMDB na Constituinte seria a luta pela anistia ampla. Dentro desse quadro, Vilson de Souza cobrava de seu partido, que mantivesse os compromissos históricos assumidos pelo PMDB sem que o partido se "agachasse" diante da pressão dos militares (BRASIL, 1987b, p. 424). Afinal, o partido havia se esquecido do próprio passado?

Sem mencionar o passado de repressão ou mesmo a luta de correligionários contra a ditadura, a liderança do PMDB orientava para que sua bancada não "colocasse o dedo na ferida aberta" da ditadura para, dessa forma, não encorajar os militares a empreenderem um novo golpe. $\mathrm{O}$ momento, para o $\mathrm{PMDB}$, era de cautela. $\mathrm{O}$ receio de uma regressão ao passado e o temor onipresente em relação ao retorno do autoritarismo, contaminou as estratégias políticas do presente dando à transição um caráter um tanto conservador (O’DONNELL; SCHMITTER, 1988).

Apesar de não justificar claramente o abandono dos compromissos históricos do PMDB em relação à anistia, o parlamentar Egídio Ferreira Lima (PMDB-PE) - deputado cassado em 1968 e ex-autêntico do MDB - destacou que aquele ainda era um tema delicado e envolto em emoção. Para argumentar que a Constituinte ainda não representava o momento ideal para a concessão de anistia ampla, o parlamentar destacou que o período ainda era marcado pela sobrevida do regime militar.

E nós, hoje, estamos vivendo não mais nem menos do que esta sobrevida. De lá até aqui têm sido grandes os avanços, mas avanços por etapas. Nós não estabelecemos a ruptura no processo. Como poderemos afastar o condicionamento militar, a tutela dos militares que, pelo menos, desde a Constituição Republicana pesa sobre este País, senão por um processo lento, enervante, por um fio de navalha, por um andar em terreno minado, pela consciência plena do que é o processo político, a sua dialética e as suas contradições? A anistia, meus prezados companheiros, talvez seja a concepção mais bela, mais magnânima do pensamento humano; ela é um instituto político-jurídico que apaga o passado, faz esquecer as mágoas, se deflagra como se nada 
tivesse ocorrido outrora; é o perdão, a graça total e completa, o esquecimento. Mas a anistia nem sempre é um ato abrupto e de momento, sobretudo quando o processo é complicado, como o que estamos fazendo, em que não houve ruptura com regime autoritário passado, em que estamos vivendo uma dolorosa, angustiante e tensa convivência com a sobra, com o resto, com a presença do sistema que durante vinte anos atormentou este País. (BRASIL, 1987b, p. 425).

Segundo Egídio Ferreira Lima, o que o partido assumira no passado foi o compromisso de lutar pela ampliação da anistia, mesmo reconhecendo que a medida deveria ser aplicada com cautela, lentamente, para não gerar maiores transtornos à nação. Em 1979, ao aceitar a "anistia possível” o PMDB admitiu que sua ampliação fosse tarefa para o futuro, mas tal futuro poderia não ser necessariamente a Constituinte. Para o parlamentar, o momento ainda era de cautela e, portanto, de silêncio.

Cheios de cautela e receios, a maioria dos peemedebistas optava por abrir mão de seu passado e adiar a anistia. Evidenciando suas contradições e heterogeneidades ${ }^{16}$, o PMDB demonstrava que a liderança do partido via a anistia sempre no horizonte, como promessa do futuro, busca e adiamento. Nesse sentido, Egídio Ferreira Lima destacou:

Deus queira e permita que possamos afastar do caminho os resquícios do autoritarismo e que, com esta Carta, possamos, realmente, abrir os caminhos da democracia. Mas, meus amigos não terão democracia neste País enquanto não conquistarmos, para a democracia, os militares, enquanto não fizermos com que o condicionamento em que eles se encontram, com sua visão autoritária e canhestra, não se afaste. Votar, neste momento, por anistia completa, total, justa e humana seria uma irrealidade, uma não percepção do momento; seria uma não capacidade para administrar o curso do processo histórico. Se quisermos uma democracia e acreditamos no caminho pacífico para esta democracia, temos que pagar o ônus, esperar que esta anistia se faça por 
etapas e até por conta-gotas. Sr. Presidente, o PMDB, por sua Liderança, se manifesta contra a emenda pelas razões aqui por mim expostas. (BRASIL, 1987b, p. 425).

Tem-se aqui uma das principais características do discurso do PMDB quando o assunto era a anistia: o receio presente e o legado ao futuro. Em crítica ao discurso de Egídio Ferreira Lima, Brandão Monteiro (PDT-RJ) - ex-líder estudantil que fora preso e torturado durante a ditadura - ressaltou que o partido majoritário na Assembleia estava sempre prometendo e apontando um "paraíso", um futuro distante, quando tinham a obrigação de encontrar soluções para os conflitos no presente. Desse modo, para o referido parlamentar, o PMDB estava sempre a contemplar o horizonte e se esquivando do agora, fugindo do embate (BRASIL, 1987b, p. 429).

Enquanto a liderança do PMDB não assumia a Constituinte como momento ideal para a ampliação da anistia e, dessa forma, dispunha-se a continuar esperando, partidos alinhados à esquerda como o PCB, PC do B e PSB viam na Assembleia Constituinte a oportunidade de acerto de contas com o passado. Ao mesmo tempo em que o PMDB demonstrava incoerência histórica em relação ao tema da anistia, o PCB utilizava-se do debate para legitimar sua trajetória política; não abriria mão de seu passado. O líder do partido, Roberto Freire, destacou que apesar de os comunistas terem sido as principais vítimas do regime militar, o posicionamento do PCB em favor da ampliação da anistia não se baseava em revanchismos ou perseguições sofridas ao longo da ditadura. Diferentemente da liderança do PMDB, para os comunistas, por fim, o futuro chegara e a Constituinte era o momento ideal para a cura do passado. Foi com tal argumento que os comunistas votaram a favor da ampliação da anistia debatida naquela sessão da Constituinte, apesar de conformarem-se momentaneamente com a anistia em 1979, viam na Constituinte o momento ideal para sua ampliação e para dissolução dos conflitos herdados da ditadura.

Segundo Miro Teixeira (PMDB-RJ), com memorável discurso diante do cadáver de César, Marco Antônio ressaltara que não estava ali para louvar o morto, mas para sepultá-lo sem inflamar ódios e ressentimentos contra seus algozes. Da mesma forma, segundo o 
deputado, a Constituinte não estava reunida para julgar o passado, mas para enterrá-lo sem instigar a revolta e, assim, pacificar a nação.

Não estou aqui para louvar as virtudes ou destacar os defeitos de dirigentes que assumiram o nosso País, a partir de 1964. O que pretendo [...] é enterrar um passado que pode significar para todos nós, aí sim, a partir desse momento, uma Nova República, pacificada, integrada, com todos os brasileiros unidos na construção democrática, que tanto esforço, tanto sacrifício, tantas vidas custou. [...] Pois bem, o futuro chegou. Estamos aqui reunidos em Assembléia Nacional Constituinte, e o que desejo é demonstrar que a anistia não é uma pregação da revanche; a anistia é o esquecimento, a anistia é o caminho para sairmos do discurso da unidade nacional e iniciarmos a verdadeira prática da união nacional (BRASIL, 1987b, p. 428).

Era preciso "enterrar César"; no entanto, para alguns parlamentares isso só seria possível por meio da reparação às vítimas e pela dissolução do passado. Em contrapartida, constituintes mais alinhados aos setores conservadores, argumentavam que a reparação deveria ser adiada e deixada como tarefa para as próximas gerações, uma vez que o presente ainda estava sob o controle do passado. Sobre o "morto" deveria pairar o silêncio.

Diferentemente daqueles parlamentares que pretendiam dissolver o vivido e silenciar sobre a repressão ditatorial, o comunista Haroldo Lima foi um dos poucos constituintes que clamou pelo julgamento do passado. O parlamentar - comunista histórico que sofrera torturas e prisões ao longo da ditadura - apontava a possibilidade de sepultar o vivido por meio da abertura da "caixa preta" do regime ditatorial, isto é, por meio da investigação e elucidação da história que ainda faltava, a história que ficara guardada nos porões da ditadura. De acordo com o parlamentar comunista, se havia uma oportunidade de julgar e punir o passado, a Constituinte era o espaço ideal. Segundo Haroldo Lima, a falta de punição aos torturadores gerava um sentimento de frustração nas vítimas do regime militar, frustração que se transferia para a "Nova República" 
e contaminava o presente (BRASIL, 1987b, p. 134). Sem "sepultura" esse passado continuaria assombrando o presente.

Estavam postas na Constituinte as principais questões em torno da anistia. Para que alcançassem a justiça e reparação era necessário anistiar os legalistas punidos ao longo do regime e, além disso, por meio da busca da verdade histórica, julgar e punir os agentes da repressão. Todavia, enquanto a questão dos cassados era bastante debatida, o julgamento dos torturadores continuava silenciado na Constituinte. Apenas Haroldo Lima parecia se lembrar de que milhares de pessoas foram torturadas e centenas continuavam desaparecidas. Dessa forma, os constituintes continuariam em silêncio e os discursos de Haroldo Lima pareciam ser proferidos para uma "platéia de surdos", ou mesmo, para aqueles que pareciam estar embriagados pelo "esquecimento" ou imobilizados pelo medo.

O debate sobre a anistia, naquela sessão de 16 de novembro, gerou tumulto na Assembleia, visto que a Constituinte, e principalmente o PMDB, parecia ter cedido à pressão dos militares e se acovardado diante da pressão dos Ministros. No tumulto desencadeado após a votação das propostas de Vilson de Souza (PMDB-SC), Jamil Haddad (PSB-RJ) e Brandão Monteiro (PDT$\mathrm{MA})$, das galerias e corredores do Congresso ecoava o coro: "PMDB traidor"! Inconformados, os ex-militares cercaram e hostilizaram o senador Mário Covas, líder do PMDB, aos gritos de "traidor" e "covarde". O mesmo Mário Covas que fora ovacionado no dia anterior, quando proferira um longo discurso em defesa dos quatro anos de mandato para o presidente José Sarney, após a votação da anistia, era escoltado sob xingamentos e agressões que vinham das vítimas da ditadura, vítimas indignadas diante da capitulação do PMDB em relação à ampliação da anistia aos cassados e da punição aos agentes do Estado. Segundo o jornal Folha de S. Paulo, no meio do tumulto o deputado Bandão Monteiro partiu para cima de Mário Covas aos gritos: "Vai lamber as botas dos militares". Um ex-marinheiro, chorando, gritou: "É inadmissível um cassado votar contra cassados." Segundo o periódico, acusado de traidor, Mário Covas, como representante de seu partido, apenas se deu ao trabalho de dizer que aquela era uma simples etapa, a anistia ampla viria em breve (VOTO..., 1987, p. 10). Mais uma vez o futuro 
aparecia como promessa de solução dos conflitos que provinham do passado. A reparação estaria no horizonte.

Mais ágil do que Mário Covas, Fernando Henrique Cardoso, outro destacado parlamentar do PMDB que votara contra a anistia, segundo materia da Folha de S. Paulo, deixou discretamente o plenário antes que a sessão terminasse. Revoltados com o posicionamento do PMDB, membros da comitiva dos ex-militares não anistiados mostravam cópias de um telegrama enviado pelo senador Fernando Henrique Cardoso ao Movimento pela Anistia. Em tal telegrama, o senador se comprometera a apoiar a ampliação da anistia na Constituinte. Para justificar a mudança de voto, o Correio Braziliense publicou uma declaração atribuída ao constituinte: "Foi o medo de que os urutus saíssem às ruas” (MILITARES..., 17 nov. 1987, p. 6).

Imobilizado pelo medo, o PMDB votara contra seu próprio passado e, dessa forma, rejeitara sua trajetória de luta pela anistia. A capitulação do partido refletiu-se como barganha pela aprovação, no dia anterior, de um mandato de quatro anos para o presidente José Sarney. ${ }^{17}$ Segundo a grande imprensa, a "ousadia” da Comissão de Sistematização não fora bem recebida pelos ministros militares que, supostamente, não aceitariam outra afronta vinda da Constituinte. Revoltado com a capitulação de seu partido, Fernando Lyra (PMDB-PE) interpelou o senador José Richa: "Vocês podiam dar oito anos para Sarney, mas jamais votar contra a anistia, porque isso é um compromisso histórico do PMDB” (CASSADOS..., 1987, p. 5).

Sobre a polêmica, o Jornal do Brasil publicou declarações atribuídas ao petista João Paulo Pires Vasconcelos:

O Brasil esteve na iminência de um golpe de estado, quando a Comissão de Sistematização da Constituinte votou proposta original de anistia ampla e reintegração na ativa dos militares cassados. Um acordo de última hora, feito pelo PMDB com as Forças Armadas, impediu que o golpe se concretizasse [...] (DEPUTADO..., 21 nov. 1987, p. 5).

Segundo o periódico, o interlocutor da negociação entre o PMDB e o ministro Leônidas Pires Gonçalves foi o senador Fernando Henrique Cardoso, peemedebista que negociou a anistia nos termos exigidos pelos militares e que, desse modo, barganhara a pacificação 
do passado. O silêncio, mais uma vez, era tomado como via para garantir o advento de um futuro livre do autoritarismo do passado.

Ponto cego da Constituinte, os parlamentares conviviam com a iminência de um novo golpe militar. Entretanto, segundo Renan Quinalha (2013), o que, no calor dos acontecimentos, parecia uma ameaçadora e iminente possibilidade tornou-se, pouco tempo depois, um grande blefe que apenas contribuiu para imobilizar os agentes da transição. Nessa mesma direção, a Federação das Associações de Defesa da Anistia (FADA) enviara nota aos constituintes advertindo-os acerca da pressão militar afiançada pela imprensa:

Tal recurso condenável passou a ser instrumento poderoso nas mãos dos agentes agoureiros, visando a persuadir os que, por falta de convicção e coragem, se dobram diante da patológica atoarda posta em prática, a título de intimidação política. O alvo preferido dos pregoeiros dessas manobras ilegais e violentas tem sido a causa da Anistia, exatamente em razão de ela promover a reabilitação daqueles que foram escolhidos para servir de exemplo à educação de uma sociedade que precisava ter sido humilhada pela opressão do silêncio e do arbítrio (BRASIL, 1988, p. 10411).

Blefe ou não, a pressão dos militares e do Executivo sobre a Constituinte foi fator determinante para que muitos parlamentares do majoritário PMDB, partido que tinha uma luta histórica pela anistia ainda sob a sigla do $\mathrm{MDB}$, recuassem e protelassem a anistia como tarefa do futuro.

Na sequência, diante do momento tenso e delicado, uma emenda proposta pelo deputado José Costa (PMDB-AL) - ferrenho opositor do regime militar - passou quase despercebida. De extrema importância, mas pouco debatida, a emenda propunha que os punidos com base em atos discricionários, a partir de março de 1964, pudessem recorrer ao Poder Judiciário para revisão e apreciação de cada caso a fim de reparação. A proposta de José Costa justifica-se pelo fato de a Constituição vigente proibir que os atingidos por atos da "Revolução de 1964" pudessem procurar a justiça em busca de reparação. Com 61 votos favoráveis a emenda foi facilmente aprovada. ${ }^{18}$ 
Outra emenda a ser aprovada no sentido de ampliar a anistia, beneficiou os trabalhadores civis do setor privado. Proposta pelo deputado petista João Paulo Pires, a medida visava beneficiar os sindicalistas e trabalhadores envolvidos em greves. Sem muita discussão, a emenda foi aprovada e, dessa forma, teve fim uma das sessões mais tensas e polêmicas da Assembleia Nacional Constituinte de 1987/88.

Com a aprovação de emendas que concediam uma anistia "a varejo”, a Constituinte capitulara e, melancolicamente, demonstrara que o peso do passado ainda guiava o presente e o futuro. Por ora, os parlamentares preferiram o silêncio e a construção da "democracia" sobre os escombros da ditadura. Mais tarde, quem sabe, exumariam o passado.

Dentro desse quadro de supervalorização do futuro, Mário Covas (PMDB-SP), apontou, em meio ao tumulto causado pela votação da anistia, que o problema dos militares cassados seria solucionado no plenário da Assembleia, última fase dos trabalhos constituintes (VOTO..., 1987, p. 10). De fato, o tema voltou a ser debatido durante a votação dos Atos das Disposições Transitórias em junho de 1988, mas poucos pareciam dispostos a enfrentar o passado face a face.

A crise interna do PMDB se refletiu também nas questões da anistia, se em novembro de 1987 o senador Mário Covas recuara diante da pressão militar e pela necessidade de aprovar os quatro anos para o mandato de Sarney, bem como o parlamentarismo, diante da derrota de tais temas, após a formação do Centrão ${ }^{19}$ Covas não temeu apresentar emenda que visava anistia para os ex-militares cassados após o golpe de 1964. A anistia tornara-se a última cartada dos progressistas contra a pressão do Executivo sobre a Constituinte. Muito mais do que a lembrança ou o esquecimento, a questão da anistia passou a refletir claramente os embates políticos dentro da Assembleia.

Em quatorze de junho de 1988, o tema voltou a ser debatido no plenário durante a votação dos Atos das Disposições Transitórias. ${ }^{20}$ Mais uma vez a polêmica girou em torno da anistia aos militares cassados. Desse modo, a ala progressista da Assembleia continuava a defender a necessidade de desfazer as arbitrariedades do passado 
e de devolver os direitos subtraídos daqueles que se posicionaram a favor do governo constitucional em 1964. Em contrapartida, os parlamentares alinhados ao governo argumentavam, como vinham fazendo desde o início dos trabalhos da Constituinte, que a anistia já havia sido concedida em 1979 e, dessa forma, o passado já teria sido reparado ao limite do possível. Entre as duas alas opostas, situavam-se parlamentares do PMDB. Estes, apesar de reconhecerem a necessidade de repararem o passado, defendiam que o presente não era o momento ideal para se pressionar "a ferida não cicatrizada”. Dessa forma, viam no futuro o momento propício para o enfrentamento do passado. ${ }^{21}$

Ávidos por se livrarem da responsabilidade de enfrentamento do passado, centenas de parlamentares assinaram uma emenda proposta por Aloysio Teixeira (PMDB-RJ), emenda que transferia a polêmica da anistia para o judiciário. Com tantas assinaturas, segundo Ferro Costa, ex-comandante da Marinha, cassado após o golpe de 1964, a Constituinte tinha a obrigação moral de aprovar a emenda e permitir aos cassados que recorressem ao judiciário em busca de reparação, uma vez que o artigo 181 da Carta de 1967 impedia a apreciação do Judiciário sobre os atos cometidos pelo comando do movimento de 1964. A aprovação da emenda de Aloysio Teixeira representaria um fio de esperança para que os cassados pudessem recorrer à justiça em busca de reparação, mesmo que a conta-gotas.

No dia quinze de junho de 1988, era posta em votação nova emenda acerca da anistia. Covas apresentou uma proposta de anistia aos punidos por atos administrativos desde que o judiciário comprovasse que a punição teve caráter político. ${ }^{22}$ Em tom melancólico, Covas ressaltou que aquela não era a anistia que pretendia, mas já que o argumento da cúpula militar era que os marinheiros foram punidos por atos administrativos e, portanto não anistiáveis, que estes pudessem recorrer ao judiciário para atestarem a punição política e, assim, alcançarem a anistia.

Frustrado diante da manutenção das restrições aos militares cassados e da perseverança do entulho autoritário, Lysâneas Maciel advertiu: "Não teremos a coragem de dizer, para o futuro, que esta Assembleia é livre e soberana, porque ela está sendo feita ao toque 
e ao tilintar das esporas dos militares e ao arrastar de espada do Ministro do Exército” (BRASIL, 1988, p. 773).

A derrota das emendas que visavam à ampliação da anistia seria uma mácula a ser carregada pelos parlamentares. Por terem cedido às pressões militares, segundo Lysâneas, a Constituinte não pôde corresponder às expectativas de tornar-se um "divisor de águas”, lugar e momento histórico em que o passado seria sepultado e o futuro construído totalmente livre do autoritarismo que marcara o regime anterior.

Após diversas etapas de negociações na Constituinte, a anistia foi inserida na nova Carta Constitucional com poucos avanços além dos limites permitidos pelos militares. A medida alcançou amplamente os civis, beneficiou os aviadores e aeronautas cassados a partir de 1964, os comunistas punidos em 1935 (muitos haviam morrido ou eram muito idosos, portanto a medida não teria efeito prático), os envolvidos no movimento "O Petróleo é Nosso" e, não obstante, manteve o manto do esquecimento sobre os agentes do governo envolvidos na repressão. Além disso, a Carta Magna inseriu a reparação financeira, sem retroatividade, a partir de sua promulgação. Desta forma, os punidos ao longo da ditadura teriam direito à promoção, na inatividade, dos cargos e postos que ocupariam caso não fossem atingidos pelas cassações.

Tem-se na nova Carta Constitucional a inserção da reparação financeira e a tentativa de apagar o passado autoritário. Todavia, ao longo dos debates sobre a anistia tornou-se evidente que os parlamentares assumiram o tema da reparação como uma devolução de direitos e um desfazer dos atos do passado. Nessa vertente, a reparação não assumiu um primeiro plano enquanto a busca pela punição, pela verdade e pela memória. O julgamento do passado, no que se refere aos debates sobre a anistia, apesar de ser um tema latente, foi legado enquanto tarefa as gerações futuras.

Após a análise dos debates sobre a anistia, consideramos que o silêncio em torno dos atos da repressão não pressupõe um esquecimento das arbitrariedades da ditadura, pelo contrário, o silêncio torna-se uma pista para compreendermos que o passado ainda incomodava e influenciava o presente, ou mesmo que o passado ainda se sobrepunha ao futuro naquela Assembleia. Apesar de afirmarem 
que tinham os olhos fixos no futuro, os parlamentares não perdiam as ameaças do passado de vista, mesmo que silenciosamente.

Apesar de os parlamentares serem acusados de elaborarem uma Constituição olhando demasiadamente para trás, a análise dos debates sobre a anistia evidenciou que tal olhar estabeleceu-se como uma tentativa de manter o passado ameaçador à distância. Era um olhar vigilante e cauteloso que tentava garantir o advento do futuro democrático. Contudo, a cautela e o silêncio permitiram que resquícios do passado, como o veto da anistia aos militares cassados e a falta de punição aos torturadores, contaminassem o futuro e, desse modo, perpetuassem-se no tempo.

Como já ressaltamos, silêncio não significa esquecimento. Medidas paliativas tal qual a definição da tortura como crime de lesa-humanidade, inafiançável, inanistiável e imprescritível, dãonos pistas de que os constituintes, conscientes das agruras do passado - embora em silêncio - tentavam prevenir o futuro para que o passado não se repetisse. Dessa forma, a "Constituição cidadã" demonstra uma clara preocupação com o passado, preocupação traduzida em uma tentativa de resguardar o futuro para que a ditadura não retornasse.

Instalada sobre os alicerces do regime autoritário, a transição brasileira acenava para um prolongamento. Se a princípio a Constituinte era vista como o epílogo da transição, o desenrolar dos trabalhos e a "coautoria" dos Ministros Militares nos principais temas da Constituição leva-nos a afirmar que o enfrentamento do passado, bem como a reparação das arbitrariedades, pontos fundamentais para a dissolução dos conflitos, foram legados ao futuro, permitindo, assim, que os resquícios do passado contaminassem as novas gerações.

Mesmo que ao longo dos trabalhos da Assembleia Constituinte a maioria dos parlamentares tenha se posicionado com cautela, na sessão de promulgação da nova Carta Constitucional, em cinco de outubro de 1988, Ulysses Guimarães externou o sentimento de repúdio ao passado que espreitava sob o olhar atento dos Ministros Militares presentes na sessão de promulgação. $\mathrm{O}$ presidente da Constituinte, em discurso memorável, destacou: 
A Nação nos mandou executar um serviço. Nós o fizemos com amor, aplicação e sem medo. A Constituição certamente não é perfeita. Ela própria o confessa ao admitir a reforma. Quanto a ela, discordar, sim. Divergir, sim. Descumprir, jamais. Afrontá-la, nunca. Traidor da Constituição é traidor da Pátria. Conhecemos o caminho maldito. Rasgar a Constituição, trancar as portas do Parlamento, garrotear a liberdade, mandar os patriotas para a cadeia, o exílio e o cemitério. Quando após tantos anos de lutas e sacrifícios promulgamos o Estatuto do Homem da Liberdade e da Democracia bradamos por imposição de sua honra. Temos ódio à ditadura. Ódio e nojo. (Aplausos) Amaldiçoamos a tirania aonde quer que ela desgrace homens e nações. Principalmente na América Latina. [...] O Estado prendeu e exilou a sociedade com Teotônio Vilela. A anistia libertou e repatriou. A sociedade foi Rubens Paiva, não os facínoras que o mataram. (Aplausos acalorados). Foi a sociedade mobilizada nos colossais comícios das Diretas Já que pela transição e pela mudança derrotou o Estado usurpador. (GUIMARÃES, 1988).

Com o discurso de promulgação, como afirmou o jornalista Carlos Castelo Branco, Ulysses

levantou o véu da anistia e olhou para trás e para dentro num incômodo reviver de lágrimas sufocadas. Pode ser que assim ele tenha sentimentos e ressentimentos e tenha contribuído para enterrar um passado que não deve mais voltar (O DISCURSO..., 1988, p. 2).

Se com tal discurso, como afirmou o jornalista, Ulysses levantou o véu da anistia, não foi capaz de removê-lo. Pelo contrário, contribuiu para que o pacto de silêncio fosse selado por meio da perspectiva apresentada em seu pronunciamento de que a nova Constituição representaria um rompimento com o passado. A partir daquele dia cinco de outubro de 1988, Ulysses e os constituintes lançavam uma nova camada no soterramento do passado. Nesse 
sentido, a experiência continuou "esquecida" em algum lugar do passado; restava, ao futuro, encontrá-la.

\section{BETWEEN SILENCE AND NOISE: THE AMNESTY IN THE CONS- TITUENT ASSEMBLY OF 1987/88}

Abstract:. This text aims at analyzing the debates on amnesty and the uses of past in the Brazilian Constituent Assembly (1987/88) set up after the Military Dictatorship (1964-1985). The debates have elucidated that the past was negotiated, reinterpreted and propagated during a process of political transition which sought to lead the country out of a discretionary regime and into a consolidation of a democratic era. Between the remembrance and the forgetfulness - by means of constant negotiations around amnesty -, the game stands forward and the political strategy to men who were involved in the rise of a new regime in the country. Hence, the dictatorial past was negotiated as from political and memorial clashes established during the context of transition which culminated in the plenary of the Constituent Assembly. By the debates risen over amnesty as well as the analysis of the Journals, Annals, magazines and memorialistic works of the Constituent Assembly the magazines and memorialistic, this text is highly committed, therefore, to assess the strategies, the negotiations and, also, the interpretation about the past in this period. In addition, this work is concerned with investigating the uses of the past in the matter of the political clashes, silences and noises which together have left their marks, scars and unsolved questions. Otherwise stated, this work can be taken as a complex interlocution settled down between the memory and history realms.

Keywords: Amnesty. Memory. Brazilian Constituent Assembly (1987/88).

\section{Notas}

${ }^{1}$ No Canto XIX da Odisséia, é narrado o episódio em que Ulisses, disfarçado de mendigo, é reconhecido por sua ama Euricléia: "A velha, que tomara na palma da mão a perna de Ulisses, ao apalpá-la, reconheceu a cicatriz; largou o pé, que caiu dentro da bacia, o bronze ecoou, o vaso oscilou e a água derramou-se pelo solo. Então, seu coração, a um tempo, foi tomado de tristeza e de alegria, os olhos se lhe encheram de lágrimas, a voz se lhe tolheu na garganta. E tocando no queixo de Ulisses, disse: 'sem dúvida, tu és Ulisses, meu filho querido! E eu não o reconhecia! Foi preciso primeiro ter tocado no corpo do meu amo!”’ (HOMERO, 1978, Canto XIX, versos 467-475). 
${ }^{2}$ Memória e esquecimento são duas polaridades que estão contidas dialeticamente na palavra anistia; a anamnesis (reminiscência) e a amnésia (olvido) aí se entrecruzam em constante tensão. Do grego amnêstia, de amnêtos, olvidado, pretendia remeter ao segundo termo do binômio. Entretanto, o conteúdo político historicizado levou o termo ao entrecruzamento da memória e do olvido (GRECO, 2003).

${ }^{3} \mathrm{O}$ PMDB, partido majoritário na Assembleia contava com 260 deputados e 46 senadores, logo em seguida vinha o PFL com 118 deputados e 14 senadores, o PDS contava com 33 deputados e cinco senadores, PDT com 24 deputados e dois senadores; PTB com dezessete deputados e um senador; PT com dezesseis deputados; PL com seis deputados e um senador; PDC com cinco deputados e um senador; PCB e PC do B cada um com três deputados; PSB com um deputado e um senador; PSC com um deputado e PMB com um senador.

${ }^{4}$ Após intensa campanha popular que contou com a mobilização da imprensa, de intelectuais, de instituições, de vítimas da ditadura e de seus familiares, em 1979 foi aprovada a Lei 6.683, polêmica Lei de Anistia, assinada pelo então presidente General João Batista Figueiredo. A Lei de anistia beneficiava os envolvidos em crimes políticos e conexos ocorridos entre dois de setembro de 1961 até 28 de agosto de 1979, data de promulgação da lei. Apesar de anistiar os exilados e banidos, além dos próprios agentes do governo, Figueiredo não concedeu o benefício aos que haviam participado da luta armada, os chamados "terroristas". Além disso, os servidores civis e militares deveriam apresentar requerimento junto a Comissão, nomeada pelo Presidente da República, para possível reversão ao antigo cargo. Diante da impunidade dos agentes do governo e da dificuldade de reversão aos seus antigos postos, as vítimas rechaçaram a associação entre anistia e esquecimento; queriam reparação. Iniciou-se um longo debate sobre a possibilidade de punição aos agentes da ditadura. Os desdobramentos da lei de anistia de 1979 transpuseram o período de transição; dessa forma, o tema foi debatido na Assembleia Constituinte de 1987/88 e chegou até os dias atuais (BRASIL, 1982).

${ }^{5}$ A Assembleia Constituinte foi dividida em 24 subcomissões que integravam 08 Comissões Temáticas. O debate sobre a anistia apareceu primeiramente na "Subcomissão dos Direitos Políticos, dos Direitos Coletivos e Garantias" integrante da Comissão da Soberania e dos Direitos e Garantias do Homem e da Mulher; em seguida o debate apareceu na "Subcomissão dos Direitos dos Trabalhadores e Servidores Públicos" que integrava a Comissão da Ordem Social. Os relatórios produzidos por tais subcomissões e comissões foram encaminhados para a Comissão de Sistematização, encarregada de organizar o projeto para votação em plenário. Apesar de o tema ter passado pelas subcomissões e comissões, optamos, para o espaço deste artigo, abordar mais detidamente o debate 
no plenário a partir do projeto apresentado pela Comissão de Sistematização visto que esta sintetizou os projetos anteriores.

${ }^{6}$ As eleições para a Constituinte foram realizadas em quinze de novembro de 1986, mesmo pleito que elegeu os governadores e deputados estaduais. O PMDB teve uma significativa vitória eleitoral; elegeu 21 dos 22 governadores estaduais - só não elegeu em Sergipe, onde não havia lançado candidato - e conseguiu maioria no Congresso Nacional, consequentemente, constituiu maioria na Assembleia Nacional Constituinte. Todavia, a ampla maioria do PMDB naquela Assembleia não pressupõe que na Constituinte predominou as tendências progressistas. Vista como uma etapa do processo de transição política, a Constituinte estava composta por uma elite socioeconômica com ampla maioria de graduados de nível superior e tutelada pelas forças conservadoras. Estudos realizados acerca do perfil socioeconômico e político dos Constituintes apontam para um predomínio político do centro, de acordo com David Fleischer (1988), 217 dos 559 constituintes tiveram passagem pela ARENA, partido que apoiou o regime autoritário. $\mathrm{O}$ autor observou que a maior bancada da Assembleia Constituinte - a bancada do PMDB - era integrada por quarenta ex-integrantes do PDS, partido que sucedeu a ARENA após a reforma partidária de 1979.

${ }^{7}$ Durante as discussões em plenário, de acordo com dados apontados pelo historiador Daniel Aarão Reis Filho (2014), cerca de dez mil pessoas circulava todos os dias pelos corredores e salas do Congresso Nacional, com vistas a lutar por seus interesses, a persuadir e barganhar votos. Os grupos de pressão, chamados lobbies, agiam em nome de diferentes bandeiras, todos com olhos bem fixos no futuro. Dentre os lobbies que pressionavam a Constituinte em torno do tema da anistia, podemos destacar a Federação das Associações de defesa da Anistia (FADA) e o grupo Tortura Nunca Mais.

${ }^{8}$ Durante os trabalhos da Assembleia Nacional Constituinte, o lobby dos militares cassados se organizou na Federação das Associações de Defesa da Anistia (FADA), tal grupo não representava apenas os militares cassados após o golpe de 1964, mas também os envolvidos no levante comunista de 1935 e os que participaram da campanha "o Petróleo é Nosso". Formada por vários grupos de cassados, a FADA pretendia incluir na nova Constituição uma anistia ampla que beneficiasse todos os punidos arbitrariamente durante a ditadura (MILITARES..., abr. 1987).

${ }^{9} \mathrm{O}$ ministério do Presidente José Sarney contava com os seguintes Ministros Militares: Leônidas Pires Gonçalves (Exército), Henrique Sabóia (Marinha), Octávio Júlio Moreira Lima (Aeronáutica), Paulo Campos Paiva, Paulo Roberto Coutinho Camarinha e Valbert Lisieux Medeiros de Figueiredo (Estado-Maior das Forças Armadas) e Ivan de Souza Mendes (SNI).

${ }^{10} \mathrm{O}$ lobby das Forças Armadas, comandado pelo general Werlon Coaracy de Roure, contava com doze oficiais das três armas. Além de oficiais, as Forças 
Armadas contavam com o apoio de alguns parlamentares como o senador Jarbas Passarinho. Entre os temas tratados na Constituinte, os Ministros Militares e o lobby das Forças Armadas exerceram pressão sobre a definição constitucional acerca da função das Forças Armadas, a manutenção da defesa interna com parte de suas funções, manutenção do Conselho de Segurança Nacional, anistia, competência dos Tribunais Militares ou a permanência da obrigatoriedade do serviço militar.

${ }^{11}$ Concedia anistia a todos os que, no período compreendido entre dezoito de setembro de 1946 e primeiro de fevereiro de 1987 foram atingidos por motivações políticas ou por qualquer diploma legal, atos de exceção, institucionais ou complementares, e aos que foram abrangidos pelo Decreto Legislativo no 18 , de quinze de dezembro de 1961, bem como aos atingidos pelo Decreto-lei $\mathrm{n}^{-}$864, de doze de setembro de 1969, assegurando promoções na inatividade, ao cargo, emprego, posto ou graduação a que teriam direito se estivessem no serviço ativo. (BRASIL, 1987d).

${ }^{12}$ Com 93 membros, a Comissão de Sistematização representava o momento mais importante do processo constituinte. A Comissão era composta pelos relatores das 24 subcomissões e pelos oito presidentes e oito relatores das Comissões Temáticas. Para presidir a Comissão onde seria elaborado o texto final da nova Carta Magna do país, fora designado o senador Afonso Arinos (PFL-RJ). A relatoria do projeto ficou a cargo do deputado Bernardo Cabral (PMDB-AM). As tendências majoritariamente progressistas dos presidentes e relatores das subcomissões e comissões engrossariam as fileiras da "esquerda" na Comissão de Sistematização. Entretanto, tal composição era pouco representativa no plenário.

${ }^{13}$ Bernardo Cabral fez um trabalho de formatação dos textos aprovados nas Comissões Temáticas transformando-os em um único projeto. Esse primeiro texto foi chamado de "Projeto A" e foi encaminhado com 496 artigos para uma primeira rodada de discussão em plenário. As emendas propostas foram analisadas pelo relator que apresentou novo texto (Cabral I). Após nova rodada de proposição de emendas, foi apresentado em 05 de setembro um novo substitutivo (Cabral II). Nesse texto, o relator tentou conciliar as demandas do Executivo e das Forças Armadas com as principais demandas da Constituinte, porém os integrantes da Comissão de Sistematização decidiram aprovar o "Projeto A". ${ }^{14}$ Bernardo Cabral era deputado federal pelo MDB quando fora cassado pelo AI-5 e teve sua carreira de professor universitário interrompida. Quando Cabral apresentou um projeto de anistia restrita, o deputado Paulo Ramos ressaltou que o parlamentar tentava ignorar a sua história: "não acredito que o Constituinte Bernardo Cabral tenha perdido a lembrança de que foi um homem cassado e que sofreu a amargura da cassação, dos direitos políticos cassados 
e não contemple com uma anistia digna aqueles que estão aí abandonados à própria sorte." (BRASIL, 1988).

${ }^{15}$ A sessão do dia 16 de novembro de 1987 foi marcada por grande tensão, dia da votação das emendas relacionadas à anistia, Marinheiros e praças tentavam ocupar as galerias para acompanharem a votação, entretanto, como reclamou o parlamentar Jamil Haddad, as portas foram fechadas para evitar tumulto diante da votação de tema tão polêmico. A primeira emenda a ser votada era de autoria do constituinte Vilson de Souza (PMDB-SC) e propunha anistia aos punidos por atos administrativos; a segunda emenda a ser votada era de autoria de Jamil Haddad (PSB-RJ) e objetivava o pagamento de atrasados aos anistiados; a terceira, proposta por Brandão Monteiro (PDT-MA) estendia a anistia aos marinheiros, soldados e cabos da Aeronáutica. As três propostas foram rejeitadas.

${ }^{16}$ A proposta de anistia aos cassados por atos administrativos dividiu a bancada do PMDB. Parlamentares de grande destaque no partido como Bernardo Cabral, Mário Covas e Fernando Henrique Cardoso votaram contra a proposta de ampliação alinhando-se ao posicionamento de bancadas conservadoras como do PDS e PFL. Uma minoria de peemedebistas votou a favor da proposta de Vilson de Souza, alinhando-se aos parlamentares com tendências mais progressistas como os da bancada do PCB e do PC do B.

${ }^{17}$ Enquanto os Ministros Militares alegavam que o mandato de Sarney deveria abranger seis anos, parte significativa dos Constituintes - principalmente do PMDB - pleiteava que o mandato de Sarney durasse apenas quatro anos. No meio do conflito, Sarney se pronunciou em rede nacional afirmando que seu mandato seria de cinco anos.

${ }^{18}$ Dentre os 27 votos contrários, não figurou o voto de Mario Covas e Fernando Henrique Cardoso, depois do episódio da sessão anterior os dois destacados parlamentares do PMDB haviam deixado o recinto.

${ }^{19}$ Descontentes com a aprovação do "Projeto A" em detrimento dos substitutivos, os parlamentares mais conservadores, que teriam dificuldades para alterarem qualquer artigo do projeto aprovado pela Sistematização, se rebelaram contra o regimento em novembro de 1987. O projeto de mudança do Regimento Interno da Constituinte foi aprovado em três de dezembro de 1987. A partir da mudança do Regimento, houve uma "virada de mesa" na Constituinte e a esquerda progressista perdeu espaço para um grupo suprapartidário de centrodireita denominado "Centrão".

${ }^{20}$ Lysâneas Maciel (PDT-RJ) e Raquel Cândido (PFL-RO) apresentaram emenda que visava o pagamento de aposentadoria aos militares cassados pelo movimento de 1964. Além da emenda fundida pelos dois parlamentares, o comunista Roberto Freire também apresentou proposta de anistia aos que foram punidos por atos 
administrativos. Novamente a reintegração dos cassados causaria polêmica, não apenas na Constituinte, mas também no Planalto e na grande imprensa. ${ }^{21}$ É difícil dividir as alas progressistas e conservadoras da Assembleia usando apenas os partidos como referência, uma vez que, principalmente após a formação do Centrão as lideranças partidárias perderam força e os posicionamentos individuais se evidenciaram. Um exemplo disso é o posicionamento da constituinte Raquel Cândido (PFL) que se tornou uma das principais defensoras da anistia aos cassados enquanto a liderança de seu partido era totalmente contra a ampliação da medida. Além disso, podemos citar a heterogeneidade do PMDB que não entrava em acordo em relação aos temas mais polêmicos da Constituinte. Apesar dessas ambiguidades partidárias, tentamos situar o posicionamento dos partidos tendo como referência a maioria dos votos concedidos por cada agremiação às emendas acerca da anistia. Dessa forma, após a análise das votações nominais, podemos afirmar que se posicionaram contra a ampliação da anistia para os militares cassados o PDS, PTB, PFL, parte do PMDB e os pequenos de direita como PL, PDC e PMB. Em contrapartida, a maioria dos parlamentares do PDT, PT, PCB, PC do B, PSB e parte do PMDB se posicionaram a favor da anistia.

${ }^{22}$ Reproduzo a emenda na íntegra: "Concede-se igualmente anistia a todos os servidores militares que em decorrência dos fatos ocorridos em 1964, tenham sido atingidos por atos administrativos, desde que sentença judicial, proferida em ação proposta no prazo de cento e oitenta dias, reconheça que a punição tenha decorrido de motivação exclusivamente política, assegurando-se-lhes os direitos e vantagens previstos na emenda constitucional no 26 , de 27 nov. 1985.”

\section{Referências}

A ANISTIA, na forma como está no projeto, não tem cabimento. Jornal do Brasil, 27 jul. 1987.

BARBOSA, Alaor. Meu diário da Constituinte. Brasília, DF: [s.n.], 1990.

BARBOSA, Rui. Anistia Inversa: caso de Teratologia Jurídica. 2. ed. Rio de Janeiro: Tip. do Jornal do Commercio, 1896.

BRASIL. Câmara dos Deputados. Assembléia Nacional Constituinte (ANC). Comissão de Sistematização. Suplemento B. 21 $1^{\underline{a}}$ Reunião Ordinária. Diário [da] ANC, Brasília, DF, 1988. Disponível em: <http://imagem.camara.gov.br/ constituinte_principal.asp>. Acesso em: 8 jun. 2017. p. 768. 
. Câmara dos Deputados. Assembléia Nacional Constituinte (ANC). Comissão da Soberania e dos Direitos e Garantias do Homem e da Mulher. Subcomissão dos Direitos Políticos, dos Direitos Coletivos e Garantias. Relatório e Anteprojeto, v. 74. Diário [da] ANC, Brasília, DF, 1987a. Disponível em: 〈http://imagem.camara.gov.br/constituinte_principal.asp〉. Acesso em: 28 maio 2017.

. Câmara dos Deputados. Assembléia Nacional Constituinte (ANC). Comissão de Sistematização. Suplemento C. Diário [da] ANC, Brasília, DF, 1987b. Disponível em: 〈http://imagem.camara.gov.br/constituinte_principal. asp>. Acesso em: 9 jun. 2017.

. Câmara dos Deputados. Assembléia Nacional Constituinte (ANC). Comissão de Sistematização. Ata de comissões. Diário [da] ANC, Brasília, DF, 1987c. Disponível em: <http://imagem.camara.gov.br/constituinte_principal. asp>. Acesso em: 8 jun. 2017.

. Câmara dos Deputados. Assembléia Nacional Constituinte (ANC). Comissão de Ordem Social. Relatório e Anteprojeto. Diário [da] ANC, Brasília, DF, 1987d. Disponível em: <http://www2.camara.leg.br/atividade-legislativa/ legislacao/Constituicoes_Brasileiras/constituicao-cidada/o-processo-constituinte/ comissoes-e-subcomissoes/comissao7/comissao7>. Acesso em: 20 mar. 2017.

. Congresso Nacional. Comissão Mista sobre a anistia. Anistia: documentário organizado por determinação do Presidente da Comissão Mista do Congresso Senador Teotônio Vilela. Brasília, DF, 1982. 2 v.

CASSADOS em 64 se revoltam contra a rejeição. O Globo, p. 5, 17 nov. 1987. CONSERVADORES acusam Bisol de defender Socialismo. $1^{\circ}$ caderno, Jornal do Brasil, Rio de Janeiro, p. 5, 9 jun. 1987.

DEPUTADO do PT diz que houve ameaça de golpe. Jornal do Brasil, Belo Horizonte, 21 nov. 1987.

O DISCURSO e suas emoções. Coluna do Castello. Jornal do Brasil, p. 2, 8 out. 1988.

FERRAZ, Joana D’Arc Fernandes. Os desafios da preservação da memória da ditadura no Brasil. In: ABREU, Regina; CHAGAS, Mario de Souza; SANTOS, Myrian Sepúlveda (Org.). Museus, coleções e patrimônios: narrativas polifônicas. Rio de Janeiro: Garamond, 2007.

FLEISCHER, David. Perfil socio-econômico e político da constituinte. In: GURAN, Milton (Coord.). O processo constituinte 1987-1988. Brasília: AGIL, 1988. 
Entre silêncios e ruídos: a anistia na assembleia...

GRECO, Heloisa. Dimensões funcionais da luta pela anistia. 559 f. Tese (Doutorado em História)-Universidade Federal de Minas Gerais, Belo Horizonte, 2003. GUIMARÃES, Ulisses. Íntegra do discurso presidente da Assembléia Nacional Constituinte, Dr. Ulysses Guimarães, 1988. Disponível em: < http://www2.camara. leg.br/camaranoticias/radio/materias/CAMARA-E-HISTORIA/339277-INTEGRA-DO-DISCURSO-PRESIDENTE-DA-ASSEMBLEIA-NACIONAL-CONSTITUINTE,--DR.-ULYSSES-GUIMARAES-(10-23).html>. Acesso em: 12 jun. 2017.

HALBWACHS, M. A memória coletiva. São Paulo: Vértice, 1990.

HOMERO. Odisséia. Tradução de Antônio Pinto de Carvalho. São Paulo: Editora Abril, 1978.

JELIN, Elizabeth. Los Trabajos de la Memoria. Madrid: Siglo XXI de España, 2001. . (Comp.). Las Conmemoraciones: las disputas em las fechas "in-felices". Madrid: Siglo XXI de España, 2002.

LOWENTHAL, David. Como conhecemos o passado. Tradução de Lúcia Haddad. Projeto História: revista do Programa de Estudos Pós-Graduados de História, São Paulo, v. 17, p. 63-201, 1998.

MARTINS, Roberto Ribeiro. Liberdade para os brasileiros: anistia ontem e hoje. Rio de Janeiro: Civilização Brasileira, 1978.

MILITARES ficam sem anistia. Correio Braziliense, Brasília, DF, p. 6, 17 nov. 1987.

MILITARES anistiados se organizam para criar lobby na Constituinte. Jornal do Brasil, Rio de Janeiro, 8 abr. 1987.

MINISTROS militares vetam anistia com reintegração. Jornal do Brasil, 25 jun. 1987.

MINISTROS militares não aceitam anistia. Correio Braziliense, Brasília, DF, 25 jun. 1987.

O’DONNELL, G.; SCHMITTER, P. Transições do regime autoritário: primeiras conclusões. São Paulo: Vértice; Revista dos Tribunais, 1988.

OLIVEIRA, Eliézer Rizzo de. De Geisel a Collor: Forças Armadas, transição e democracia. Campinas: Papirus, 1994.

OUTRA tática para a anistia. O Estado de São Paulo, São Paulo, 13 jun. 1987. POLLAK, M. Memória, esquecimento, silêncio. Estudos Históricos, Rio de Janeiro, v. 2, n. 3, p. 3-15, 1989. 
QUINALHA, Renan Honório. Justiça de transição: contornos do conceito. São Paulo: Outras Expressões; Dobra Editorial, 2013.

REIS FILHO, Daniel Aarão. Ditadura e democracia no Brasil: do golpe de 1964 à Constituição de 1988. Rio de Janeiro: Zahar, 2014.

RICOEUR, Paul. A memória, a história, o esquecimento. Tradução de Alain François et al. Campinas: Unicamp, 2007.

SARNEY transmite a seus líderes veto de militar a ampliação da anistia. Jornal do Brasil, p. 2, 14 jun. 1988.

VASCONCELOS, Cláudio Beserra de. A política repressiva contra militares no Brasil após o golpe de 1964. In: ENCONTRO REGIONAL DE HISTÓRIA, 12., 2006, Niterói. Comunicações... Rio de Janeiro: ANPUH, 2006.

VERÍSSIMO, Luís Fernando. A mãe do Freud. Porto Alegre: L\&PM, 1985.

VOTO contra anistia causa tumulto e Covas sai escoltado do plenário. Folha de S. Paulo, São Paulo, p. 10, 17 nov. 1987.

YERUSHALMI, Yosef Hayim. "Reflexiones sobre el olvido". In: YERUSHALMI, Y; LORAUX, N.; MOMMSEN, J. C.; MILNER, G. Vattimo. Usos del Olvido. Argentina: Nueva Visión, 1998.

Recebido em: 28/06/2017

Aprovado em: 30/09/2017 